\title{
環境計画と環境情報システム
}

\author{
武内和 彦* 恒川篤 史 ${ }^{* *}$ 李東 根***
}

\section{Establishment of Environmental Information System for Environmental Planning}

Kazuhiko TAKEUCHI ${ }^{*}$ Atsushi TsuneKAWA ${ }^{* *}$ and Dong-kun LEE ${ }^{* *}$

\section{I. 環境計画の概念}

「環境計画」は広範囲な内容を示す言葉であるが，ここでは「地域環境管理計画」を中心に議論をすすめ る。

日本の環境行政は，種々の環境計画に係わる構想，計画，指針を提示している。上位レベルでは国レベ ルの環境保全長期構想があり，首都圈，近畿圏，および中部圈では，広域環境管理指針を策定中である。 一方, 都道府県, 市町村に掞いては，地域環境管理計画がある。地域の環境を保全し，良好な環境を創出 していくための核となる計画で，環境計画体系の中の Key 計画として位置づられる。また，最近は， アメニティタウン計画やェコポリス計画などの実践的な計画も策定されつつある。

地域環境管理計画でとくに期待されるのは，総合計画や土地利用計画を環境的側面からサポートするこ とである。これまでの環境計画は, 公害部局の専門計画に終わることが多かった。しかし，公害防止から 快適環境の創出へと環境行政の重点が移りつつある中で, むしろ地域全体の環境の質を高めるという視点 から，地域の総合計画や土地利用計画をコントロールすることが地域環境管理計画に求められている。

ここ数十年に和ける環境計画の変遷を見ると，大きく三つのステージに分けられる。

第一は，1960年代後半に始まるいわゆる公害の時代に確立された環境計画である。この時代には，大気 污染や水質污濁を防止する施策の確立が，環境行政の中心的課題であった。

しかし，1976 年には OECD が，日本は「污染を減少させるのに大いに成功したが，環境に関する不満 を除去することには成功しなかった」といら指摘をした。1980年代の日本の環境行政は，こうした反省に たち, 自然環境の保全やアメニティの創出を政策課題に取り込みながら, 総合的な環境管理へと発展して いった。これが第二のステージである。地域環境管理計画は，まさにそうした要請を受け，総合的な環境 管理を推進すべく，その成果が期待されているのである。

一方，1980年代後半から，地球環境問題が注目され始めた。地球温暖化やオゾン層破壞，酸雨性による 森林被害や砂漠化といった地球環境問題は，その影響の及ぶ範囲や発生メカニズムがグローバルな点に特 質があるが，その解決のためには畢竟一人一人の行動と，ローカルな地域環境管理が大きなカギを握って いるといえる。

Think Globally, Act Locally の言葉に代表されるよらに, 地球環境保全の視点からみた地域環境管 理のあり方を考えるべさ時代が，いよいよ到来したのである。1990年代は，第三のステージとして，地 球環境時代を意識しながら，地域の生態系を保全・再生するための環境計画を考えるべき時代になるだる 亏。

\footnotetext{
* 東京大学農学部 * Faculty of Agriculture, The University of Tokyo

** 環境庁国立環境研究所 ** National Institute for Environmental Studies

**** 東京大学農学系大学院 *** Graduate Student, The University of Tokyo
} 


\section{II. 地域環境管理計画の理論的支柱}

地域環境管理計画には，大きく，三つの理論的な支柱があると考光る（環境庁環境管理課編 1986）。 第一は「環境資源論」である。地域環境は人々の生存や生産活動の基盤であり, それ自身有限な資源で ある。この有限な環境を次世代に引き継ぐためには，資源の賦存量を見積り，その適正な配分と，環境容 量の範囲内での合理的利用を考兵なければならない。

第二は「地域環境論」である。地域環境は，気候，地形，地質，水，土壇，動・植物，といったさまざ まな環境要素が密接につながって，一つのシステム（地域生態系）を形成している。地域特性を生かした 計画を策定するには，地域生態系を総合的・構造的に理解し，地域の自然的・社会的特性を把握する必要 がある。

第三は「環境管理論」である。もともと環境管理 (environmental management) という概念は，スト ックホルムの国連人間環境会議で提案されたものである。資源としての環境は，管理されることで，長期 的汇維持される。

最近では，環境を保全・管理してとそ，持続可能な 開発が 実現できるといら考光方から，持続的開発 (sustainable development) といら概念が提唱されている。すでに生じた環境問題を解決するだけでなく， 将来生じ得る問題を予測し，それを未然に防ぐ，いわば予見的な環境管理が求められているのである。

\section{III. 環境管理計画を支援する環境情報システム}

こうした環境管理計画を支援する武器として期待されているのが「(地域) 環境情報システム」である。 地方自治体によってさまざまな名称が用いられているが，基本的には，三つのサブシステムから構成され ている。すなわら，環境情報を収集し入力する環境モニタリングシステム，情報を保存する環境データベ ースシステム，情報を利用し，環境の評価，将来予測などを行う情報解析システムである。

このような環境情報システムが，環境管理計画と一体的に議論され，計画策定に際してその役割が非常 に期待されているのは，先に述べた環境管理計画に拈ける三つの理論的支柱と深い関係にある。

まず環境資源論という点から見ると，一般の主題図からだけでは資源の賦存量を計量的に把握すること は困難である。地図情報のほかに，各種の統計情報を含み，それらを解析し，賦存量を算出できるのが数 值情報の特質である。

地域環境論といら視点でみると，地域の環境資源の保全・創出の方策を示すためには，あらかじめ地域 生態系を総合的・構造的に把握することが重要である。環境情報システムは, 数值地図を単にオーバーレ イするだけでなく，情報処理技術を通して，個々の環境要素を体系化，構造化することが可能なのであ る。

環境管理論の視点でみると，地域の環境評価や将来予測飞もとづく適正な管理方策の提示に環境情報シ ステムが使えると期待される。環境データベースを用いた地域環境の評価は，環境管理指針や将来の環境 像を提示する際に必要である。

秃たコンピュータ・シミュレーションによって，現在の環境が将来どう変わるかを予測したり，政策 オプションの効果を見積もることで，予見的な環境管理を行うための非常に強力な武器となり得る。

\section{IV. 環境情報システムの問題点}

以上のように，環境情報システムに大きな期待が寄せられているにもかかわらず，その利用実態は惨々 たるものである。環境管理計画で環境情報システムが本当に活用された例は，無き㳊等しいと言っていい だろう。なぜそうなったのか，理由を考えてみたい。

第一は, 地域環境データベースに収められる地理情報の精度に関する問題である。メッシュ・マップの 
場合、メッシュの大きさが計画に対して粗すぎると問題がしばしば起こる。いかなる目的で，いかなるデ 一タを収集するか，スケール観をともなって正しく議論されていない。

このことは，既存のデータベース（国土数值情報や細密数值情報など）にどこまで頼るか，という問題 とも関連する。データベースの構築を, 単に経費の観点から考光るのではなく, 対象となる空間スケール とのか亦いで考光ることが必要である。

例光ば，環境保全長期構想などの国土レベルの環境計画に対しては, 国土数值情報, メッシュ気候值, 全国植生データなどの $1 \mathrm{~km}$ 標準メッシュ程度のデータが有用である。しかし, それらが有用なのは, せ いぜい広域環境管理指針のレベルまでであろう。都道府県や市町村など自治体レベルでは, 一般に $1 \mathrm{~km}$ メッシュでは粗すぎる。

したがって，自治体レベルの場合，データベースを独自に作成することが必要となる。データベースの 構築には, 測量, 計測, 調査などでオリジナルなデータづくりからはじめる場合と, 既存の地図情報から データを作成する場合とが考兄らる。 5 万分の 1 の土地分類図や現存植生図は, 泳湆日本全体を覆いつ つある状況にあり，多くの場合そらした既存の主題図からのデータベース化が可能である。

われわれも, 多摩川中流域に打ける事例研究の中で, 既存の地図を利用してデータベースを作成した が，ある程度の労力さえ確保すれば, メッシュ・データの作成はそれほどむずかしいものではない（李他 1989)。

第二は，収集されるデータの内容に偏りがあるといら問題である。基本的に，収集されやすいのは，す でに地図化されている情報, もしくは地図上から計測できる情報である。例光ば, 国土数值情報のなかに は, 標高に関するものとして, 平均・最高・最低標高, 傾斜度, 起伏量, 谷密度など実に多項目にわたる データが収集されている。その一方で，例えば土壌については，土壤分類のみである。また，動・植物の 分布・生息域のように，地域の自然環境を把握するうえで必要とされる情報でも,データベースとしては 整備されていなかったり, かりに整備されていても精度の悪いものが多い。

また，地理情報の形態でみると，日本の場合には，国土情報整備事業がベースになっているために，い わゆるメッシュ情報（ラスタ情報）が中心となっている。そのため，本来ならばベクタの形態が好ましい ような点的, 線的な情報までも, メッシュ情報として整備されていることが問題としてあげられる。

第三は, データの解析関する問題である。環境情報システムに期待される役割として, 科学的, 合理 的な環境の評価や地域の将来環境の予測がある。しかし, 実際には, この部分のシステムの開発が著しく 遅れている。

とくに問題となるのは, (1)土壤分類や植物群落データなどの定性的（名義尺度）データの解析手法, (2) 水質環境などの自然科学的な評価と,アメニティ環境などの社会科学的な評価との総合化の手法, (3)モデ リングやコンピュータシミュレーションによる科学的な将来予測の手法, である。こうした問題を解決す るためにわれわれも検討を始めたところである。

第四は，環境情報システムを構築するらえでの行政側の問題である。環境情報システムは，環境管理計 画を策定する段階で，一体的に整備されるケースが多いが，その場合には，計画の策定とデータベースの 構築が同時並行的飞進行することになる。計画策定とデータベース構築が同じ年度の事業に組み込まれて いては，データベースを計画策定に役立てることが困難であり，事実上不可能なことも多い。

さらに，計画が策定された後のデータベースのフォローアップが十分でないのる問題である。予算の性 格上データベースをアップデートするに十分な費用を捻出することがでさないのである。そのために，環 境情報システムを環境アセスメント使抢らとしても，データがすでに古すぎて使えない，あるいは必要 な情報整備ができない，といった事態が予想される。 

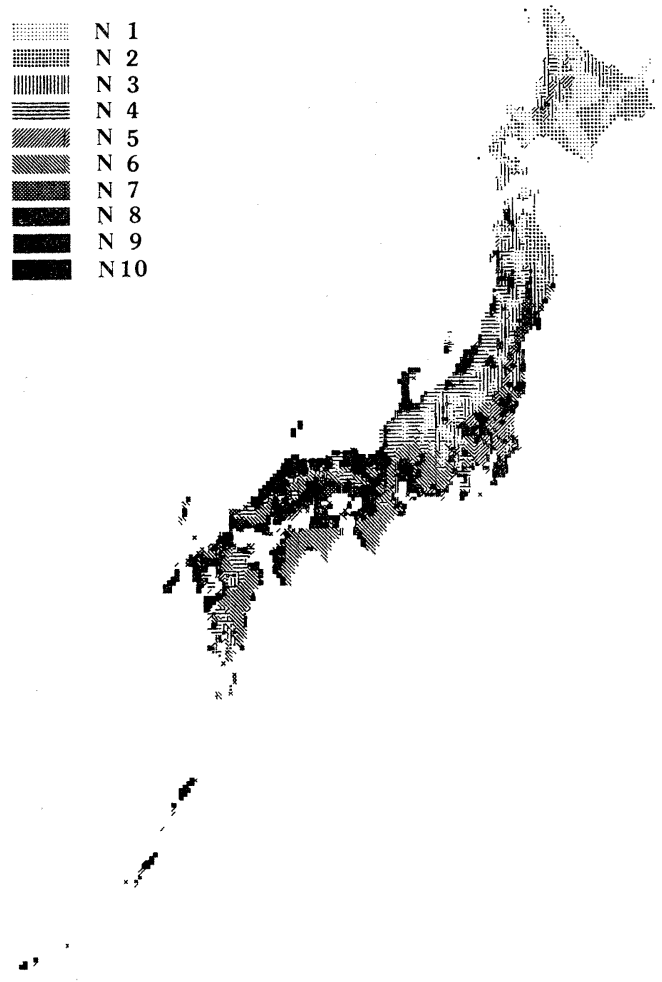

図 1 多変量解析手法を用いた日本の自然地域区 分 (TAKEUCHI et al. 1990)

\section{V. 環境情報の解析手法}

つぎに，環境情報の解析手法について，われ われが提案している手法を折り込みながら，概 説してみよう。

\section{1）地域生態系の構造的把握}

地域環境論の立場から, 地域生態系を構造的 に把握する作業が必要になると指摘した。その ような要請に応え得る手法として，われわれが 提案しているのが，多変量解析手法を用いた客 観的な環境構造の把握と環境特性に基づく地域 区分の手法である。

例えば，図 1 は $1 \mathrm{~km}$ 標準メッシュを用いて 作成した日本の自然地域区分である（日本野生 生物センター 1989 ; TAKEUCHI et al. 1990)。

ここではまず，メッシュ気候値をもとにした 因子分析による気候区分, 地質, 地形, 土壌分 類をもとにした数量化III類による土地自然区 分, 環境庁の全国植生データをもとにした植生 区分の三つの基礎的な環境区分を作成した。さ らに，この三つの区分を数量化而類を用いて統 合し，その結果（サンプルスコア）をもとにク ラスタ分析を行って10の自然地域を抽出した。 こうして日本の総合的な自然地域区分を作成 し, 各自然地域の特質と, 自然環境要素の相互

の関係を把握することができた。

多摩川中流域に打いても同様の手法を試みたことがある（李他 1989）。ここではすず, 東京都環境デー タベース，首都圈細密数值情報などを基礎資料として，500m メッシュの流域環境データベースを作成し た。流域の神奈川県部分については，地図の読みとりから新たにデータを作成した。地質，地形，土㙥， 現存植生, 土地利用，人口密度といったデータを用いて数量化而類による分析を行い，さらにクラスタ分 析によりグループ Aからグループ Fまでの 6 地域を区分した。表 1 はこのようにして区分された各地域の 環境特性をまとめたものである。

このような手法は, 理論的には, 地球全体の自然地域区分から, 地域レベルの環境構造の把握まで, さ まざまな空間レベルに適用できると考光られる。

\section{2）環境の評価}

一口に環境の評価といっても, 地形, 土壌, 植生, 水質などの自然環境を評価する場合と, アメニティ や景観，生活の潤いといった人文・社会環境を評価する場合とでは，当然その評価手法は異なってくる。

自然環境の評価を試みた最近の事例として，農林水産省・農業環境技術研究所を中心とした「国土資源 プロジェクト」がある。この研究は，環境資源の機能評価の体系化を行っている。例えば，洪水防止機能 については, 表層地質, 傾斜, 地形分類, 土地利用, 土䁃, 年降水量といったデータを用いた評価式を算 出している。表 2 はこの評価式を用いて, ゴルフ場開発にともなら洪水防止機能の低下を予測した例であ る。 
表 1 多摩川中流域における環境単位（各グループごとの環境特性）（李他 1989）

\begin{tabular}{|c|c|c|c|c|c|c|}
\hline & 地 質 & 地 形 & 土 壤 & 植 & 土地利用 & $\begin{array}{l}\text { 人口密度 } \\
\left(\text { 人 } / \mathrm{km}^{2}\right)\end{array}$ \\
\hline グループA & 固結堆積物 & 山地 & 褐色森林土 & 人工林 & 山林 & $0-1,999$ \\
\hline グループ B & 半固結堆積物 & 丘陵地 & 褐色森林土 & 二次林 & 山林 & $0-1,999$ \\
\hline グループC & ローム層 & 丘陵地 & 黒ボク土 & $\begin{array}{l}\text { 二次林・耕地・草地 } \\
\text { ・緑が多い住宅地 }\end{array}$ & 山林・造成地 & $0-5,999$ \\
\hline グループD & 口ーム層 & 高 - 中位段丘 & 黒ボク土 & 緑が少ない市街地 & 住宅地 & 14,000 以上 \\
\hline グループE & ローム層 & $\begin{array}{l}\text { 高・ 中位段丘 } \\
\text { ・低位段丘 }\end{array}$ & 黒ボク土 & $\begin{array}{c}\text { 緑が少ない市街地 } \\
\text { ・草地・耕地 }\end{array}$ & $\begin{array}{c}\text { 耕地・住宅地 } \\
\text { ・造成地 }\end{array}$ & $\begin{array}{l}6,000 \\
-9,999\end{array}$ \\
\hline グループ F & $\begin{array}{l}\text { 未固結堆積物 } \\
\text { (磞質堆積物) }\end{array}$ & $\begin{array}{l}\text { 低位段乒 } \\
\text { - 低地 }\end{array}$ & $\begin{array}{l}\text { 黒ボク土 } \\
\text { ・低地土 }\end{array}$ & 緑が少ない市街地 & $\begin{array}{c}\text { 件宅地 - 耕地 } \\
\text {. 公共用地 }\end{array}$ & 6,000 以上 \\
\hline
\end{tabular}

表 2 千葉県夷隅地域におけるゴルフ場建設にともなう「洪水防止機能」の低下予測 （評価式は農林水産技術会議事務局・農業環境技術研究所 1985～1988による）

\begin{tabular}{|c|c|c|c|c|c|c|}
\hline 市町村 & 進捗状沉 & $\begin{array}{l}\text { 面 積 } \\
(\mathrm{ha})\end{array}$ & 現状の評価值 & $\begin{array}{l}\text { 開 発後 } \\
\text { 予 測 值 } \\
\end{array}$ & $\begin{array}{l}\text { 現 状 の } \\
\text { 総合ランク }\end{array}$ & $\begin{array}{l}\text { 開 発 後の } \\
\text { 総合ランク }\end{array}$ \\
\hline \multirow{2}{*}{ 浦 市 } & 調整中 & 83.4 & 33 & 23 & III & II \\
\hline & 調整中 & 23.2 & 35 & 25 & IV & II \\
\hline \multirow{4}{*}{ 大多喜町 } & 着 工 & 92.0 & 33 & 25 & III & II \\
\hline & 着工 & 97.9 & 33 & 25 & III & II \\
\hline & 調整中 & 118.3 & 33 & 25 & III & II \\
\hline & 調整中 & $?$ & 35 & 25 & III & II \\
\hline \multirow{3}{*}{ 桋 隅 町 } & 着 工 & 88.9 & 35 & 25 & III & II \\
\hline & 着 工 & 89.3 & 33 & 25 & III & II \\
\hline & 調整中 & 72.3 & 35 & 25 & III & II \\
\hline 御 宿 町 & 着 工 & 84.4 & 35 & 27 & IV & III \\
\hline 大 原 町 & 調整中 & 97.6 & 35 & 25 & IV & II \\
\hline 岬 & 調整中 & 79.3 & 35 & 25 & IV & II \\
\hline
\end{tabular}

評価式 $\mathrm{Y}=\mathrm{X}_{1}+2 \mathrm{X}_{2}+\mathrm{X}_{3}+3 \mathrm{X}_{4}+2 \mathrm{X}_{5}+\mathrm{X}_{6}$

$\mathrm{X}_{1}$ : 表層地質, $\mathrm{X}_{2}$ : 傾斜, $\mathrm{X}_{3}$ : 地形分類, $\mathrm{X}_{4}$ : 土地利用, $\mathrm{X}_{5}$ : 土壤, $\mathrm{X}_{6}$ : 年降水量 総合ランクによる評価

$$
\text { I : 小 }(<18), \text { II : やや小 }(19 \sim 26), \text { III : 中 }(27 \sim 34), \text { IV : やや大 }(35 \sim 42), \text { V : 大 }(>43)
$$

また，農林水産省・資源課は，「地域資源管理システム」を検討している（日本土壌協会・農林水産省資 源課 1989）。この事業では，地域資源の賦存量の把握と，機能評価に基づく地域資源管理計画手法の開発 に取り組んでいる。

その概要を図 2 に示す。まず，土地，水，生物などの地域資源について，それぞれを構成する形成因子 （地質，土㙴，降水なぞ）を摘出し，その形成因子別の賦存量を把握する。つぎに，その形成因子のもつ属 性（地域資源の諸機能に対して果している役割や性質）を明らかにし，これらの属性をランクづけし，順 次組み合わせて，内在する機能を摘出・評価するのである。 


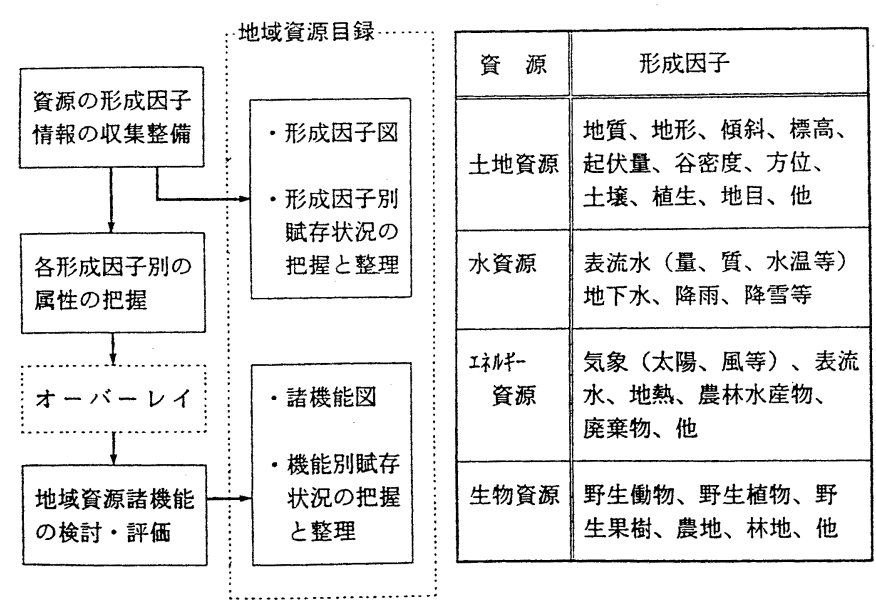

図 2 地域資源の機能別賦存量把握のフロー （日本土㙴協会・農水省資源課 1989）

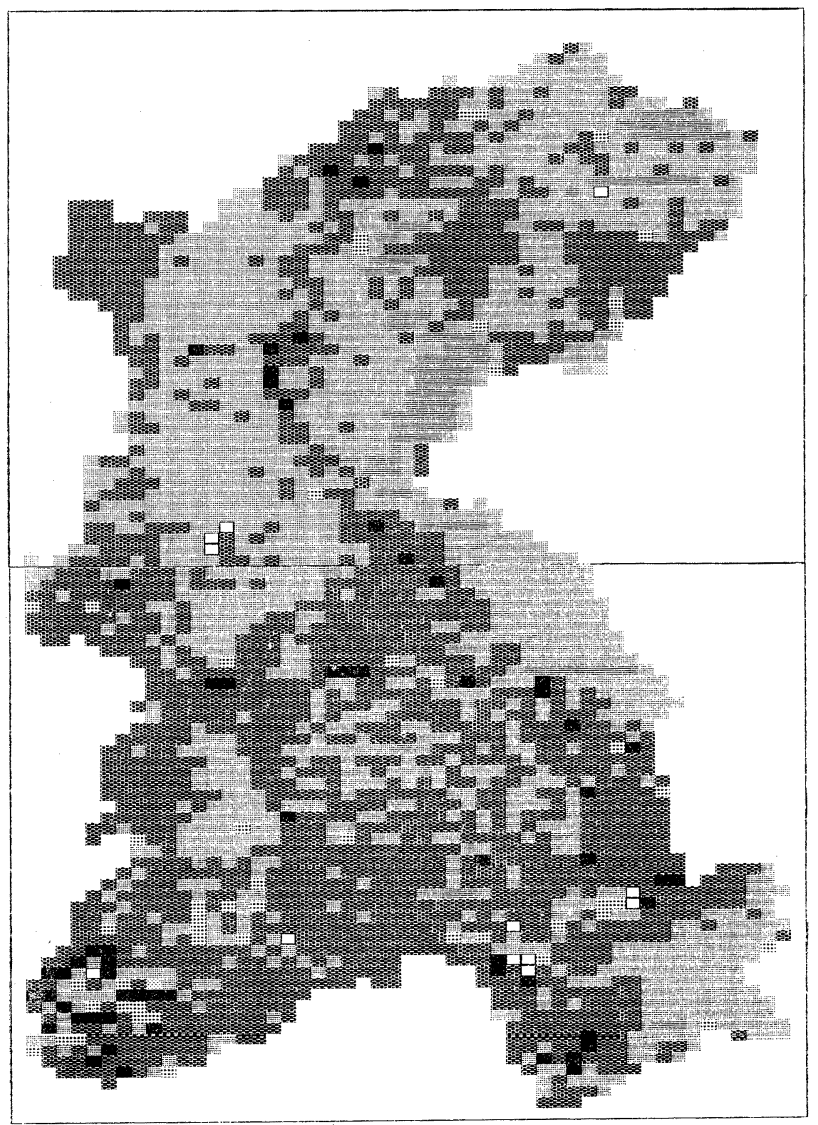

図 3 飛驒川流域に招ける河川流量調整機能（農水省東海農政局 1990）
この作業は, いくつかの流 域を対象に行っているが，流 域が広域にまたがる場合に は，国土数值情報の活用も検 討されている。図 3 は，その 一例で, 岐阜県の飛驒川流域 を対象とした河川流量調整機 能の評価結果である（農水省 東海農政局 1990)。

一方, アメニティ環境の評 価などには，アンケートによ る住民意識調査のような社会 科学的な手法がよく用いられ る。

われわれが多摩川中流域で 行った事例研究では, 1984年 に東京都が実施した「都民 の快適環境に関する意識調 查」結果を活用した。まず 多変量解析手法により, 地 域を環境構造からみたいく つかのグループに区分した （図 4)。つぎに意識調査の 結果をグループ毎に集計 乙, 自然系優占のグループ Aの地域を除いて, 統計分 析を行った。

意識調査は, 環境を 4 つ の側面で評価するものであ った。すなわち，(1)総合評 価 (Q1)，(2)まちのすがす がしさと静けさの評価 $(Q$ 2), (3)自然とのふれあいの 評価 (Q3)，(4)まちの美し さとゆとりの評価 (Q4) で ある。

分析の結果, Q2, Q3 は 都市化が最もすすんでいる グループD地域の評価が低 く, Q4 の評価は工業地域 が多いグループE地域が最 低である，といったように 
地域特性と対応した環境評価結果を得ることができた。

\section{3) 環境の将来予測とその評価}

現状の環境の評価とあわせて，環境管理計画では，将来環境を予測し，環境管理にかかわる政策オプシ ョンの評価や,アセスメントの支援を行らこと重要である。それには, 環境評価の变動を予測するための コンピュータシミュレーションが有効である。

多摩川中流域に拉ける事例研究では, 土地利用, 現存植生および人口密度について, 将来の変動を 5 年 ごとに予測した。土地利用と現存植生については, マルコフ連鎖モデルを用いて，人口密度については重 回帰分析を用いて, 将来の変動の予測を行った。

つぎに, 先に示した評価の項目を目的変数とし, 地形, 土地利用, 人口密度, 現存植生, 各地域区分を 説明変数として重回帰分析 による評価モデルを作成し た。これに土地利用, 現存 植生, 人口密度, の变化予 測值をインプットして, 将 来の環境評価を予測でき た。

図 5 は,グループ F 地域 の将来環境の評価予測を, 環境要因のコントロールの 有無で比較したものであ る。すなわち，現在の住宅 地率で緑の多い住宅地を維 持した場合，コントロール しないときと比べて，環境 評価水準の低下が抑えられ

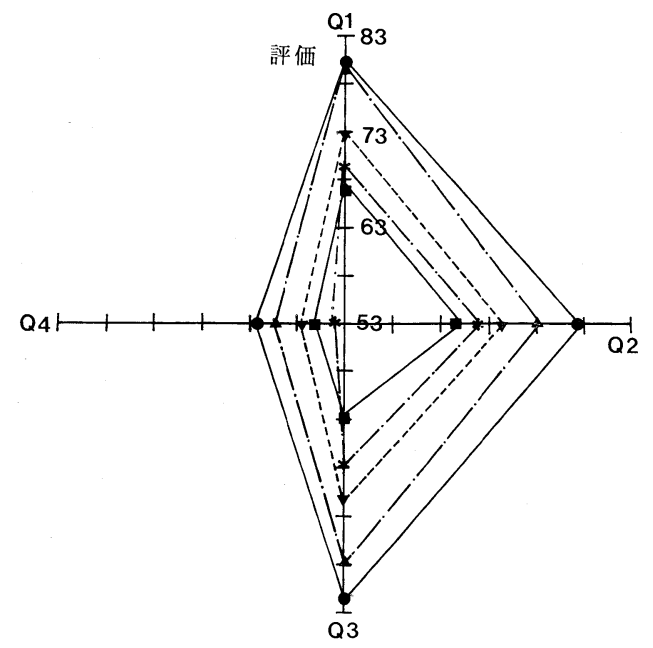

図 4 各グループごとの環境評価結果

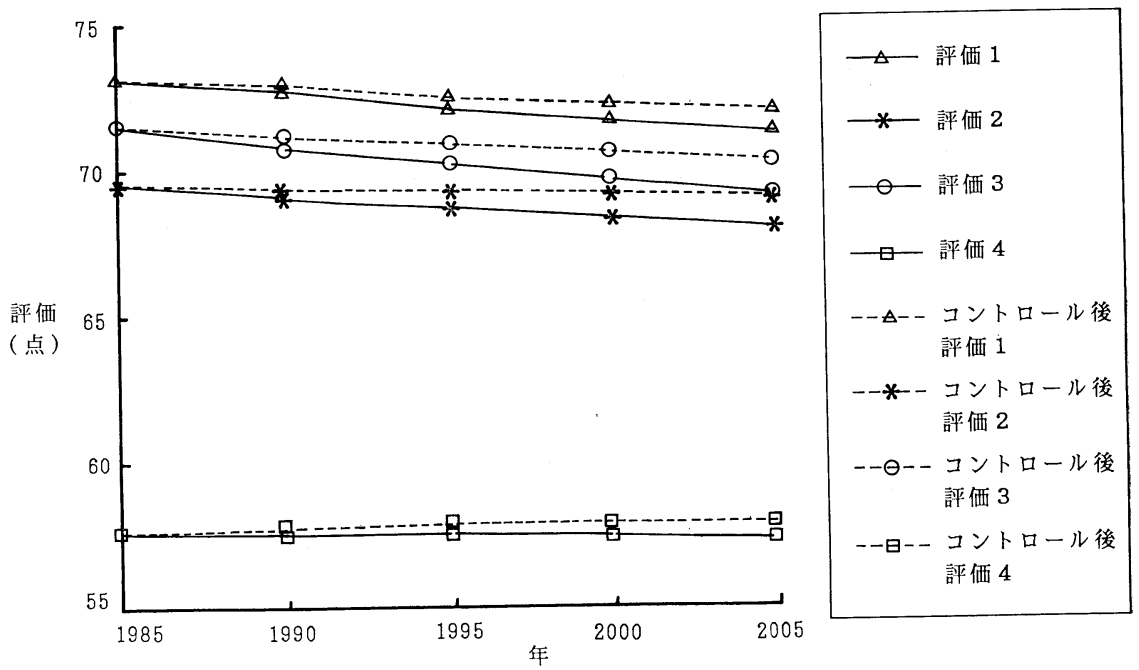

図 5 グループ F地域に㧍ける将来の環境評価予測と変動要因のコントロール後の 予測との比較 


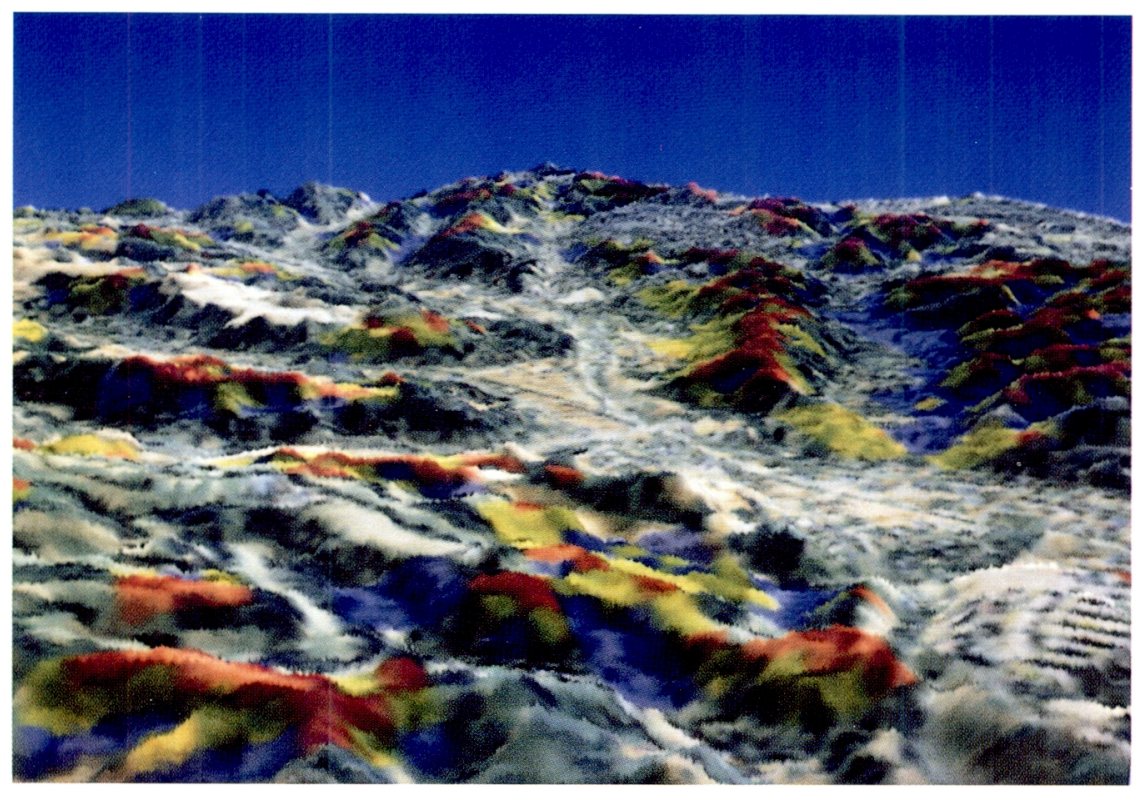

図 6 樹林地の視認性評価 (三段階) と立体空中写真画像のデジタル・オーバレイ (斎藤他 1990)

環境配虑

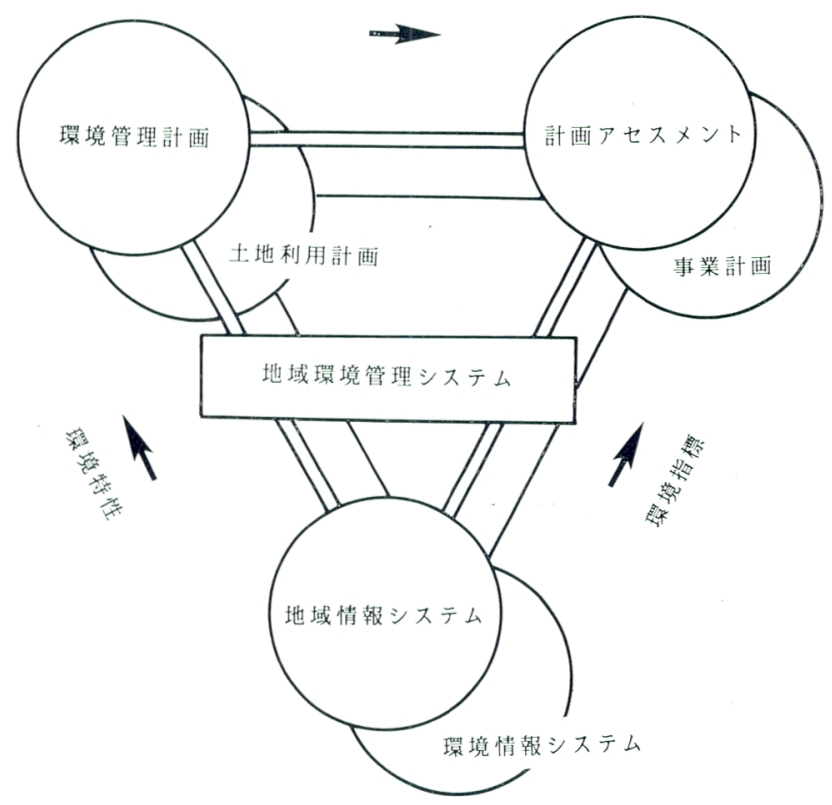

図 7 地域環境管理システムの考え方

\section{ると子測された。}

この研究では, 将来予測を将来環 境の評価につなげる道筋を示したに 過ぎず，方法論的には検討すべき余 地が大いに残されている。今後この 課題を解決することが，環境情報シ ステム成功のカギを握っているとい える。
4）景観シュミレーションし環境 計画

最後に, 景観シミュレーションに ついて述べてみたい。近年コンピ ュータグラフィックス (Computer Graphics； CG) や数值地形モデル (Digital Terrain Model: DTM) といった手法が急速に発展し，これ までと異なるリアルな景観表現が， 数值情報を用いて行光るようになっ てきた。

景観評価や景観計画は, 環境計画 そ非常にかかわりが深い。生態学的 
な意味で環境が守られ，さらに景観的な良さが維持されれば大変望ましいと考えられる。

そらいら意図でわれわれは，文部省科学研究費・試験研究飞より「快適環境形成のための生態・景観予 測評価システムの整備と最適化モデルの開発」（研究代表者：武内和彦）を行っている（斎藤他 1990）。 ここでは広域景観情報のリアルな可視化のため, フルカラーCG によるデジタルオーバーレイと地形レン ダリングを行い，そこに環境評価の結果を上書きするシステムを開発中である (図 6 )。今のところ景観表 現江重点が抒かれているが，将来的には数值情報を基礎とした環境情報システムと，その最終的な表現と しての景観シミュレーションを統合するシステムを開発しようとしている。

こうした手法により，環境影響を数值的に予測するばかりではなく，視覚的な景観の変化として把握す ることが可能になり，環境アセスメントや環境管理計画への住民の積極的な参加をうながすことにつなが ると期待される。

\section{VI. 環境情報システムへの期待}

図７亿示されるような環境管理の総合的な棵組久を「環境管理システム」と呼ぼう。このシステムで は，環境管理計画，環境情報システム，計画アセスメントが，有機的に結びつけられることによって，そ れぞれの効果をいっそう高めることになると期待される。

環境計画は，土地利用計画や総合計画と連動させることで，いっそうその重要性が高まる。しかし，そ うした一体化の障壁となるのが行政の縦割り構造である。環境情報システムと都市情報システムや他の関 連システムとの間で，情報の共有化や一体的利用を図り，情報面からこの縱割り構造を乗り越光ていけな いだららか。

情報システムが共有化されることにより，環境に対する配慮が，都市計画や総合計画のなかにいらか知 らず盛り込まれていく。環境計画に怙ける環境情報システムの意義として，そうした副次的な効果も期待 したいのである。

\section{文献}

環境庁環境管理課編（1986）：地域環境管理計画・計画策定の手引き。公害研究対策センター, $188 \mathrm{p}$. 李 東根 ・恒川篤史・武内和彦 (1989): 多摩川中流域における環境基礎情報の整備と環境構造 の把 握. 造園雑誌 52-5, 288-293.

日本土壤協会・農林水産省資源課（1989）：地域資源管理システム 画像処理システム操作等説明書. $224 \mathrm{p}$.

日本野生生物研究センター（1989）：第 3 回自然環境保全基䃈調查報告書一解析編一, $525 \mathrm{p}$.

農林水産技術会議事務局・農業環境技術研究所（1985 1988）：「農林水産業のもつ国土資源と環境の 保全機能及びその維持増進に関する総合研究」研究報告書 (第 1 集 第 5 集)。農林水産技術会議 事務局・農業環境技術研究所, $99 \mathrm{p}, 195 \mathrm{p}, 109 \mathrm{p}, 122 \mathrm{p}, 172 \mathrm{p}$.

農林水産省東海農政局（1990）：地域資源管理システム形成調查報告書一飛驒川流域地区 I 一. 46 p. 斎藤 馨・塩田敏志・熊谷洋一・武内和彦・興水 肇・山本幹雄 (1990) : CG によるフルカラー・ デジタル・オーバレイと地形レンダリング：PIXEL No. 93，96-99.

武内和彦・李 東根 (1988)：環境管理計画のフレームワーク：造園雑誌，52-2，95-104.

TAKeuchi, K., TsunekawA, A. and Ikeguchi, H. (1990): Numerical classification of natural regions of Japan. Geogr. Rep. Tokyo Metropol. Univ., No. 25, 269-287.

(1990年10月17日受理) 